\title{
Use of a process-based model for assessing the methane budgets of global terrestrial ecosystems and evaluation of uncertainty
}

\author{
A. Ito ${ }^{1,2, *}$ and M. Inatomi ${ }^{2}$ \\ ${ }^{1}$ Center for Global Environmental Research, National Institute for Environmental Studies, Tsukuba, Japan \\ ${ }^{2}$ Japan Agency for Marine-Earth Science and Technology, Yokohama, Japan \\ *now at: Tsukuba, Japan
}

Correspondence to: A. Ito (itoh@nies.go.jp)

Received: 1 July 2011 - Published in Biogeosciences Discuss.: 15 July 2011

Revised: 21 December 2011 - Accepted: 31 January 2012 - Published: 15 February 2012

\begin{abstract}
We assessed the global terrestrial budget of methane $\left(\mathrm{CH}_{4}\right)$ by using a process-based biogeochemical model (VISIT) and inventory data for components of the budget that were not included in the model. Emissions from wetlands, paddy fields, biomass burning, and plants, as well as oxidative consumption by upland soils, were simulated by the model. Emissions from ruminant livestock and termites were evaluated by using an inventory approach. These $\mathrm{CH}_{4}$ flows were estimated for each of the model's $0.5^{\circ} \times 0.5^{\circ}$ grid cells from 1901 to 2009, while accounting for atmospheric composition, meteorological factors, and land-use changes. Estimation uncertainties were examined through ensemble simulations using different parameterization schemes and input data (e.g., different wetland maps and emission factors). From 1996 to 2005, the average global terrestrial $\mathrm{CH}_{4}$ budget was estimated on the basis of 1152 simulations, and terrestrial ecosystems were found to be a net source of $308.3 \pm$ $20.7 \mathrm{Tg} \mathrm{CH}_{4} \mathrm{yr}^{-1}$. Wetland and livestock ruminant emissions were the primary sources. The results of our simulations indicate that sources and sinks are distributed highly heterogeneously over the Earth's land surface. Seasonal and interannual variability in the terrestrial budget was also assessed. The trend of increasing net emission from terrestrial sources and its relationship with temperature variability imply that terrestrial $\mathrm{CH}_{4}$ feedbacks will play an increasingly important role as a result of future climatic change.
\end{abstract}

\section{Introduction}

Biogeochemical feedbacks within the terrestrial biosphere in response to climatic change occur through the flows of trace gases, and especially greenhouse gases (GHGs, particularly $\mathrm{CO}_{2}, \mathrm{CH}_{4}$, and $\mathrm{N}_{2} \mathrm{O}$ ). These exchanges with the atmosphere play a unique role in the Earth-atmosphere system, and have therefore attracted considerable attention (Arneth et al., 2010). After $\mathrm{CO}_{2}, \mathrm{CH}_{4}$ is the second-most-important GHG except water vapor in accounting for past increases in atmospheric radiative forcing (IPCC, 2007). Various biogeochemical processes control the global $\mathrm{CH}_{4}$ budget, including anthropogenic factors such as emissions from the fossil fuel industry, landfills, livestock ruminants, biomass burning, and rice cultivation. However, because of the complexity and heterogeneity of $\mathrm{CH}_{4}$-related processes, there remains a wide range of uncertainty in our understanding of the global $\mathrm{CH}_{4}$ budget and its variability (e.g., Matthews and Fung, 1987; Hein et al., 1997; Bousquet et al., 2006).

Terrestrial ecosystems are key components in the Earthatmosphere system. In terms of the global $\mathrm{CH}_{4}$ cycle, the terrestrial ecosystem budget is highly uncertain because (1) sources and sinks are heterogeneously distributed over the land surface, (2) wetlands and animals (i.e., livestock ruminants and termites) both produce substantial $\mathrm{CH}_{4}$ emissions, and (1) human impacts have severely altered the biogeochemical processes related to atmosphere-ecosystem $\mathrm{CH}_{4}$ exchange. Wetland ecosystems may represent the largest sources of anaerobic $\mathrm{CH}_{4}$ production and emission, but a consistent value for the total flux from these ecosystems has not been obtained: recent estimates range from 100 to $230 \mathrm{Tg} \mathrm{CH}_{4} \mathrm{yr}^{-1}$ (IPCC, 2007). Also, aerobic emissions of $\mathrm{CH}_{4}$ from plants (Keppler et al., 2006) may prove to be substantial sources of $\mathrm{CH}_{4}$; Martinson et al. (2010) discovered a new source at about $1.2 \mathrm{Tg} \mathrm{CH}_{4} \mathrm{yr}^{-1}$ from tank bromeliads in neotropical forests. These newly discovered phenomena and the wide range of estimated values show the immaturity of our understanding of the global $\mathrm{CH}_{4}$ budget. In addition, many observations have indicated that the rate of increase of atmospheric $\mathrm{CH}_{4}$ concentrations is temporally variable, with high incremental rates during the 1980s and markedly lower rates from the 1990s to the early 2000s (Dlugokencky et al., 1994, 2011). Our inability to reliably specify how much of 
this variability is attributable to changes in terrestrial source and sink strengths may limit our ability to predict changes and discuss options for mitigating future climate change.

Modeling of terrestrial $\mathrm{CH}_{4}$-related processes is also immature, because the production and consumption processes are complicated and occur heterogeneously in space and time. Low concentrations and small fluxes of $\mathrm{CH}_{4}$ make it difficult to obtain the gas exchange data required for model development and validation. Several empirical models have been developed to evaluate $\mathrm{CH}_{4}$ exchange by wetlands on the basis of observed data (e.g., Christensen and Cox, 1995; Cao et al., 1996; Walter and Heimann, 2000; Zhang et al., 2002; Zhuang et al., 2004; Petrescu et al., 2010; Ringeval et al., 2010; Tian et al., 2010; Wania et al., 2010; Riley et al., 2011). For example, Wania et al. (2010) developed a mechanistic model (LPJ-WHyMe) of $\mathrm{CH}_{4}$ emission from northern peat-lands that included regulatory hydrological processes. Ringeval et al. (2010) assessed climate- $\mathrm{CH}_{4}$ feedback by using a process-based wetland $\mathrm{CH}_{4}$ emission model coupled with a dynamic vegetation model (ORCHIDEE). However, it is still difficult to mechanistically model the effects of the soil's chemical and physical environments (e.g., temperature, redox potential) and biological regulation (e.g., substrate limitations, microbial functional composition). Many processbased wetland models have adopted a multi-layer approach (which incurs high computational costs), because the watertable depth strongly influences $\mathrm{CH}_{4}$ production and consumption rates. Estimation of $\mathrm{CH}_{4}$ budgets in wetlands and seasonally flooded areas (e.g., inundation during rice cultivation) is important to evaluate $\mathrm{CH}_{4}$ emission at broad scales, but it requires precise topographic and hydrological information. In addition, it is generally difficult to simulate humandriven processes such as irrigation, drainage, and crop and livestock farming, even on the basis of empirical data. Development and refinement of models that simulate $\mathrm{CH}_{4}$ exchange are therefore urgent issues in research to elucidate global GHG cycles.

The objectives of our study were (1) to estimate the $\mathrm{CH}_{4}$ budget of terrestrial ecosystems at a global scale by using a process-based model for processes that are reasonably well understood and inventory data for components of the budget that were not included in the model, and (2) to discuss the range of estimation uncertainty by using multiple input datasets and calculation (modeling) schemes. We focused on the $\mathrm{CH}_{4}$ budget of terrestrial ecosystem compartments such as the vegetation, soil, and animals in both natural and human-managed areas. However, we did not consider most other anthropogenic point sources, such as fossil fuel extraction and use, mining, and landfills, because the model that we used focuses on natural and agricultural ecosystems.

\section{Data and methods}

We evaluated the global $\mathrm{CH}_{4}$ budget of terrestrial ecosystems by using a process-based terrestrial biogeochemical model (VISIT) and inventory data from 1901 to 2009 (Fig. 1). The estimates were performed at a spatial resolution of $0.5^{\circ} \times 0.5^{\circ}$ latitude and longitude. The terrestrial model simulated $\mathrm{CH}_{4}$ emissions from wetlands and paddy fields, oxidation by upland soils, emission from biomass burning, termite and livestock emissions, and plant aerobic production. Estimation uncertainty was assessed by using different calculation schemes for wetland emissions, upland oxidation, and plant aerobic production, as well as different emission factor values.

\subsection{Description of the VISIT terrestrial biogeochemical model}

\subsubsection{Model overview}

VISIT (the Vegetation Integrative SImulator for Trace gases) is a process-based terrestrial ecosystem model (Inatomi et al., 2010; Ito, 2010). We used VISIT in this study to estimate biogeochemical $\mathrm{CH}_{4}$ exchange fluxes (Fig. 1). Because this model focuses on natural and agricultural ecosystems, we did not simulate anthropogenic (urban and industrial) emissions. Processes driven by animals (i.e., by livestock ruminant and termite emissions) were not explicitly included in the model; in this study, these fluxes were evaluated separately by using inventory data (see Sect. 2.2). The model was developed from a simple carbon cycle model (Sim-CYCLE; Ito and Oikawa, 2002), in which atmosphere-ecosystem exchange of $\mathrm{CO}_{2}$ (photosynthesis, respiration, and decomposition) and intra-ecosystem carbon dynamics (e.g., allocation of photosynthate, litterfall, humus formation) were simulated by using ecophysiological submodels. Carbon dynamics are captured by using a box-flow system, which incorporates the following plant and soil carbon pools (i.e., "boxes"): leaves, stems, roots, litter, and humus. VISIT was developed on the basis of Sim-CYCLE by including a nitrogen cycle scheme and additional trace-gas exchange schemes (i.e., $\mathrm{CH}_{4}$ production and oxidation, biomass burning, emission of biogenic volatile organic compounds).

The model has been validated through comparisons with a variety of observational data at different scales. For example, comparison of the carbon dynamics at 17 sites around the world showed that the model successfully captured the productivity, biomass and soil carbon stocks of ecosystems ranging from tropical rain forests to arctic tundra (Ito and Oikawa, 2002). The net budget of GHGs $\left(\mathrm{CO}_{2}, \mathrm{CH}_{4}\right.$, and $\mathrm{N}_{2} \mathrm{O}$ ) in deciduous broad-leaved forest was compared with chamber measurements, and the model was able to capture the observed source/sink patterns (Inatomi et al., 2010). In validation of the estimated $\mathrm{CH}_{4}$ emission from inundated surfaces, the model estimated fluxes from a paddy field in Japan 


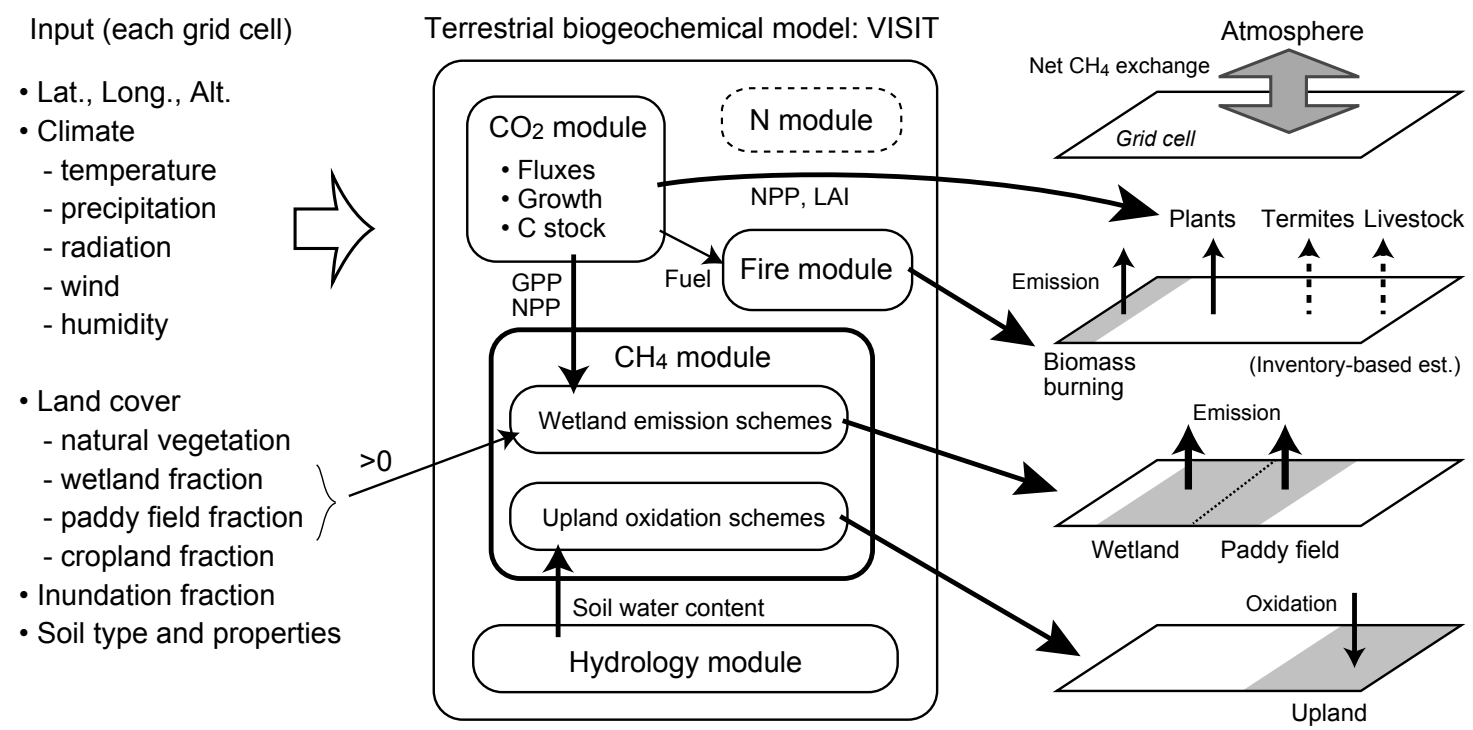

Fig. 1. Schematic diagram of process used to evaluate the terrestrial $\mathrm{CH}_{4}$ budget using the VISIT model.

(Inatomi and Ito, unpublished data) and from natural wetlands in West Siberia (Sasakawa et al., 2010). Ecosystemscale carbon budgets were compared with those observed using the eddy-covariance method, mainly at Asian sites, but the results again demonstrated the model's validity (Ito, 2008, 2010). The model has been applied in various globalscale studies, such as the analysis of interannual variability in $\mathrm{CO}_{2}$ budgets (Ito and Oikawa, 2000), off-line future projections (Ito, 2005), coupling with a climate model (Kato et al., 2009), linkage with remote-sensing data (Hazarika et al., 2005), and climate data evaluation (Saito et al., 2011).

\subsubsection{A bulk scheme for evaluating $\mathrm{CH}_{4}$ emission from wetlands and paddy fields}

Cao et al. (1996) developed a simple process-based scheme for describing $\mathrm{CH}_{4}$ emission from wetlands, in which the total (i.e., bulk ecosystem-scale) exchange of $\mathrm{CH}_{4}$ is evaluated as the difference between $\mathrm{CH}_{4}$ production and oxidation rates. Therefore, the scheme is not intended to simulate fine-scale $\mathrm{CH}_{4}$ dynamics such as the vertical profile of soil $\mathrm{CH}_{4}$ concentration and diffusion, but is instead designed to evaluate large-scale $\mathrm{CH}_{4}$ budgets by using the least possible amount of data. The $\mathrm{CH}_{4}$ production rate $(P)$ is obtained as follows:

$P=\mathrm{DS} \cdot \mathrm{FP} \cdot f(\mathrm{WTP}) \cdot f(\mathrm{TEM})$

where DS is the decomposition rate of soil organic matter (simulated in the carbon cycle scheme), FP is the proportion of the decomposed organic carbon that is transformed into $\mathrm{CH}_{4}$ (a constant average value $=0.5$ ), and $f(\mathrm{WTP})$ and $f$ (TEM) are scalar coefficients that account for regulation by the water table position (WTP) and temperature (TEM). Cao et al. (1996) used exponential functions to evaluate the environmental effects on $\mathrm{CH}_{4}$ production. The $\mathrm{CH}_{4}$ oxidation rate $(O)$ in inundated wetlands is evaluated as follows:

$O=P \cdot\left(0.60+0.30 \cdot\left[\mathrm{GPP} / \mathrm{GPP}_{\max }\right]\right)$

where GPP is the gross primary production (simulated in the carbon cycle scheme) and GPP max $_{\text {in }}$ is the seasonal maximum GPP. The parameters derived from VISIT's carbon cycle scheme (DS, GPP, and GPP max $_{\text {) }}$ ) are updated annually.

\subsubsection{A multi-layer scheme for $\mathrm{CH}_{4}$ emission from wetlands and paddy fields}

Walter and Heimann (2000) developed a mechanistic scheme for $\mathrm{CH}_{4}$ emission from wetlands. Different $\mathrm{CH}_{4}$ production and transport processes were explicitly considered in this scheme. Here, belowground processes were simulated by using a one-dimensional multi-layer system, in which the soil from the surface to a depth of $1 \mathrm{~m}$ was divided into 50 layers, each $2 \mathrm{~cm}$ thick. Temporal and vertical variations in $\mathrm{CH}_{4}$ concentration in the air $\left(C_{\mathrm{CH}_{4}}\right)$ are expressed by using the continuity equation:

$$
\begin{aligned}
& \frac{\partial}{\partial t} C_{\mathrm{CH}_{4}}(t, z) \\
& =-\frac{\partial}{\partial t} \mathrm{DF}(t, z)+\mathrm{EB}(t, z)+\mathrm{PT}(t, z)+P(t, z)+O(t, z)
\end{aligned}
$$

where $t$ and $z$ denote time and depth, respectively, DF is the diffusive flux, EB is the ebullition flux to the atmosphere, PT is the plant-mediated (i.e., through aerenchyma) $\mathrm{CH}_{4}$ flux, and $P$ and $O$ are $\mathrm{CH}_{4}$ production and oxidation, respectively, at time $t$ and depth $z . \mathrm{CH}_{4}$ production $(P)$ is calculated for soil layers below the water table as follows: 
$P(t, z)=P_{0} \cdot f_{\text {org }}(z) \cdot f_{\text {in }}(t) \cdot f(T) \cdot Q_{10}^{\left(T(t, z)-T_{\text {mean }}\right) / 10}$

where $P_{0}$ is a rate constant specific to each biome type, $f_{\text {org }}(z)$ and $f_{\text {in }}(t)$ represent the effect of substrate availability from soil organic matter and plant roots, respectively; $f(T)$ is a step-wise function of the effect of freezing on $\mathrm{CH}_{4}$ production (i.e., $f(T)=0$ at temperatures below freezing, and $f(T)=1$ at higher temperatures); $Q_{10}$ is a parameter that defines the temperature responsiveness of the processes (i.e., the change per $10^{\circ} \mathrm{C}$ temperature change); and $T_{\text {mean }}$ (in ${ }^{\circ} \mathrm{C}$ ) is the annual mean temperature. $\mathrm{CH}_{4}$ oxidation $(O)$ is calculated for soil layers above the water table, as follows:

$O(t, z)=-\frac{V_{\max } \cdot C_{\mathrm{CH}_{4}}(t, z)}{K_{\mathrm{m}}+C_{\mathrm{CH}_{4}}(t, z)} Q_{10}^{\left(T(t, z)-T_{\text {mean }}\right) / 10}$

where $V_{\max }$ is the maximum rate $\left(20 \mu \mathrm{mol} \mathrm{L}^{-1} \mathrm{~h}^{-1}\right)$ and $K_{\mathrm{m}}$ is the Michaelis-Menten coefficient $\left(5 \mu \mathrm{mol} \mathrm{L}^{-1}\right)$. The diffusive flux (DF) is calculated by using Fick's first law:

$\mathrm{DF}(t, z)=-D(z) \frac{\partial}{\partial t} C_{\mathrm{CH}_{4}}(t, z)$

where $D$ is the diffusion coefficient, which is a function of the soil's coarse pore fraction. As a boundary condition, $\mathrm{C}_{\mathrm{CH}_{4}}$ values at the bottom and top $+4 \mathrm{~cm}$ of the soil are assumed to be zero and equal to the atmospheric concentration, respectively. The model assumes that $\mathrm{CH}_{4}$ emission by ebullition (EB) occurs when $\mathrm{C}_{\mathrm{CH}_{4}}$ exceeds a threshold. Because this scheme is applied only to the wetland fraction of a cell in the model, we chose a threshold value for a vegetated land surface ( $500 \mu \mathrm{mol} \mathrm{L}^{-1}$; the model's default value). Plant-mediated flux (PT) occurs within the rooting depth, and the model accounts for the vertical distribution of roots and the plant's growth stage. The total flux (i.e., the summation of DF, EB, and PT) at the land surface represents the net $\mathrm{CH}_{4}$ budget of the atmosphere.

\subsection{4 $\mathrm{CH}_{4}$ oxidation by upland soils (Potter et al., 1996): algorithm 1}

In this scheme, $\mathrm{CH}_{4}$ uptake by soil microbial oxidation (OX) in upland (i.e., non-saturated) soils is calculated on the basis of Fick's first law:

$\mathrm{OX}=D \frac{\Delta C_{\mathrm{CH} 4}}{\Delta z}$

where $D$ is the diffusivity coefficient and $\Delta C_{\mathrm{CH}_{4}} / \Delta z$ is the $\mathrm{CH}_{4}$ concentration gradient as a function of depth in the soil $(z)$. Diffusivity $(D)$ is a function of the soil temperature and water content:

$D=D_{0} \cdot(0.9734+0.0055 T) \cdot f(\mathrm{SW})$

where $D_{0}$ is the diffusivity of $\mathrm{CH}_{4}$ in air at $5{ }^{\circ} \mathrm{C}\left(0.194 \mathrm{~cm}^{-2}\right.$ $\left.\mathrm{s}^{-1}\right), T$ is the soil temperature $\left({ }^{\circ} \mathrm{C}\right)$, and $f(\mathrm{SW})$ is a scalar coefficient function of soil water content (SW) that accounts for the difference between intra- and inter-aggregate pore spaces. Volumetric soil water content was simulated in the VISIT hydrology scheme and used to estimate the water volumes contained in the intra- and inter-aggregate pore spaces. Originally, Potter et al. (1996) assumed that the $\mathrm{CH}_{4}$ concentration gradient was constant, at $0.04 \mathrm{ppmv} \mathrm{cm}^{-1}$, for global applications. In the present study, we multiplied the gradient by the ratio of $C_{\mathrm{CH}_{4}}$ to the base concentration (1.2 ppmv) to account for the influence of atmospheric $\mathrm{CH}_{4}$ accumulation.

\subsection{5 $\mathrm{CH}_{4}$ oxidation by upland soils (Ridgwell et al., 1999): algorithm 2}

In this scheme, upland $\mathrm{CH}_{4}$ consumption (OX) is also estimated by using Fick's first law (Eq. 7). However, although diffusivity $(D)$ also varies with temperature $(T)$ and soil water content (SW), it is adjusted on the basis of the characteristics of the pore space:

$D=D_{0} \cdot(1+0.0055 T) \cdot\left[\mathrm{TP}^{4 / 3} \cdot\left(\frac{\mathrm{AFP}}{\mathrm{TP}}\right)^{1.5+3 / b}\right]$

where $D_{0}$ is the diffusivity of $\mathrm{CH}_{4}$ in free air, TP is the total pore volume, AFP is the air-filled pore volume, and $b$ is a parameter specific to the soil texture (Saxton et al., 1986). In this scheme, microbial oxidation activity is also considered by using the following equation:

$\mathrm{OX}=k_{\mathrm{d}} \cdot C_{\mathrm{CH}_{4}}(z)$

where $k_{\mathrm{d}}$ represents oxidation activity and $C_{\mathrm{CH}_{4}}(\mathrm{z})$ is the $\mathrm{CH}_{4}$ concentration in the soil air at depth $z$. The activity, $k_{d}$, is an empirical function:

$k_{\mathrm{d}}=k_{0} \cdot f(N) \cdot f(\mathrm{SW}) \cdot f(T)$

where $k_{0}$ is the base oxidation rate $\left(0.00087 \mathrm{~s}^{-1}\right)$ and $f(N)$, $f(\mathrm{SW})$, and $f(T)$ are coefficients of scalar functions that indicate the regulation of oxidation by the nitrogen input in croplands and by soil water and temperature, respectively. In this study, the scheme was separately applied to natural ecosystems $(f(N)=1.0)$ and cropland $(f(N)=0.25)$, and then the estimated fluxes were weighted by the areal fractions of these two types of land use in each cell of the grid. Also in this scheme, the $\mathrm{CH}_{4}$ concentration gradient was originally assumed by Ridgwell et al. to be constant at $0.04 \mathrm{ppmv} \mathrm{cm}^{-1}$, but we modified the gradient to account for the increase in atmospheric $\mathrm{CH}_{4}$ over time.

\subsection{6 $\mathrm{CH}_{4}$ oxidation by upland soils (Del Grosso et al., 2000): algorithm 3}

Using the US Trace Gas Network dataset, Del Grosso et al. (2000) proposed a general model of $\mathrm{CH}_{4}$ consumption in upland soils; the model consisted of two sub-models. The following equation is used for the soils of grasslands and coniferous and tropical forests, and for agricultural soils: 
$\mathrm{OX}=\mathrm{OX}_{\max } \cdot f(W, \mathrm{FC}) \cdot f\left(T, D_{\mathrm{opt}}\right) \cdot f\left(A_{g}, D_{\mathrm{opt}}\right)$

where $\mathrm{OX}_{\max }$ is the maximum $\mathrm{CH}_{4}$ oxidation rate (a function of optimal diffusivity) and $f(W, \mathrm{FC}), f\left(T, D_{\mathrm{opt}}\right)$, and $f\left(A_{g}, D_{\text {opt }}\right)$ are scalar coefficients representing the regulation of $\mathrm{CH}_{4}$ oxidation by soil water content $(W)$, the optimum diffusion coefficient $\left(D_{\text {opt }}\right)$, and soil temperature $(T)$. A second equation is used for deciduous forests:

$\mathrm{OX}=\mathrm{OX}_{\max } \cdot f($ WFPS $) \cdot f(T)$

where WFPS is the water-filled pore space, which is derived from the soil water content estimated by the VISIT hydrology scheme and based on soil physical properties (i.e., soil bulk density and solid phase density). This approach assumed that OX decreases moderately with increasing WFPS and increases linearly with increasing temperature.

\subsection{7 $\mathrm{CH}_{4}$ oxidation by upland soils (Curry, 2007): algorithm 4}

Curry (2007) modified the mechanistic scheme of Ridgwell et al. (1999) by introducing an advanced scalar coefficient for the regulation exerted by soil water on microbial oxidation activity (i.e., $f(\mathrm{SW})$ in Eq. 11). In this scheme, the soil regulation coefficient is calculated from the soil water potential, which in turn is calculated from the volumetric soil water content and is more sensitive under dry conditions (Curry, 2007). Also, the temperature dependence, $f(T)$, at subzero temperatures was modified on the basis of observations. In this scheme, the effect of atmospheric $\mathrm{CH}_{4}$ concentration is explicitly included on the basis of the assumption that most of the $\mathrm{CH}_{4}$ consumption occurs in the upper soil above a depth of $10 \mathrm{~cm}$.

\subsubsection{Emission from biomass burning}

The emission from biomass burning (BB, $\mathrm{g} \mathrm{CH}_{4} \mathrm{~m}^{-2} \mathrm{yr}^{-1}$ ) is evaluated in the model by using a generic equation developed by Seiler and Crutzen (1980):

$\mathrm{BB}=\mathrm{BEF} \cdot \mathrm{BAF} \cdot \mathrm{FL} \cdot \mathrm{BE} \cdot \mathrm{BF}$

where $\mathrm{BEF}$ is an emission factor that is specific to each gas and biome, BAF is the burnt area fraction (i.e., the proportion of each cell that burned in the model), FL is the fuel load (dry-matter storage estimated by the carbon cycle model in VISIT), and BE and BF are the burning efficiency and burned fraction, each of which is a specific parameter for each biome type. We used the BEF values of Andreae and Merlet (2001) and van der Werf et al. (2010) in this analysis: 6.8 to $9.0 \mathrm{~g} \mathrm{CH}_{4}$ (kg dry matter) $)^{-1}$ for tropical forests and 2.2 to $2.3 \mathrm{~g} \mathrm{CH}_{4}$ ( $\mathrm{kg}$ dry matter) ${ }^{-1}$ for grasslands. BAF is estimated by using the parameterization by Thonicke et al. (2001):

$$
\begin{aligned}
& \mathrm{BAF}=s \times \exp \\
& \left(\frac{s-1}{0.45 \cdot(s-1)^{3}+2.83 \cdot(s-1) 2+2.96 \cdot(s-1)+1.04}\right)
\end{aligned}
$$

where $s$ is the fraction of the length of the fire season expressed as a proportion of the total year; this fraction is affected by the fuel load (with a threshold fuel load of $>200 \mathrm{~g}$ dry-matter $\mathrm{m}^{-2}$ required to sustain combustion) and the fuel moisture content. We derived the fuel load and moisture content from the carbon cycle and from hydrological schemes, respectively.

\subsubsection{Plant aerobic emission}

Methane emission by plants under aerobic conditions (VE) was evaluated by using the emission factor of Keppler et al. (2006) and the up-scaling methods proposed by Kirschbaum et al. (2006).

Leaf-mass-based up-scaling:

$\mathrm{VE}_{\text {mass }}=\mathrm{SL} \cdot \mathrm{WL} \cdot\left[\mathrm{DL} \cdot \mathrm{VEF}_{\text {sun }}+(24-\mathrm{DL}) \mathrm{VEF}_{\text {dark }}\right]$

where SL is the growing season length, WL is leaf mass (derived from the carbon cycle model in VISIT), and DL is day length. The emission factors for living leaves $\left(\mathrm{VEF}_{\text {sun }}\right.$ under sunny conditions and $\mathrm{VEF}_{\text {dark }}$ under dark conditions) were assumed to be 374 and $119 \mathrm{ng}$ (g dry matter) ${ }^{-1} \mathrm{~h}^{-1}$, respectively (Keppler et al., 2006).

Photosynthesis-based up-scaling:

$\mathrm{VE}_{\text {photo }}=2 \cdot\left(\frac{16}{12}\right) \cdot \frac{\mathrm{NPP}}{r}\left(1+\frac{24-\mathrm{DL}}{\mathrm{DL}} \cdot \frac{\mathrm{VEF}_{\text {dark }}}{\mathrm{VEF}_{\text {sun }}}\right)$

where NPP is net primary production (model estimation) and $r$ is a unit conversion coefficient. These two estimates are expected to indicate the range of uncertainty due to the choice of up-scaling methods.

\subsection{Inventory-based estimation of $\mathrm{CH}_{4}$ emissions}

\subsubsection{Emissions from livestock ruminants}

Emissions from major livestock ruminants (water buffalo, cattle, goats, pigs, and sheep) were estimated on the basis of inventory data for animal density (number per unit area) and specific emission factors (i.e., $\mathrm{CH}_{4}$ emission per individual). The global distribution of livestock was derived from the Gridded Livestock of the World 2007 data (http://www.fao. org/AG/againfo/resources/en/glw/home.html) compiled by the Food and Agriculture Organization (FAO), of the United Nations. These data show the contemporary animal density at a $0.05^{\circ} \times 0.05^{\circ}$ resolution; we assumed that the data provided a baseline in 2005 . Temporal changes in livestock density were estimated from two inventory datasets: the FAOSTAT data compiled by the FAO (http://faostat.fao.org/) and the HYDE global land-use and emission data (Klein Goldewijk et al., 2011). The FAOSTAT dataset provides country-based livestock data from 1961 to 2009 (with a 1-yr time step), and the HYDE dataset provides region-based data from 1890 to 1990 (with a 10-yr time step). These country- and region-based data were assigned to each of the 
$0.5^{\circ} \times 0.5^{\circ}$ grids by using the national boundary data in the Gridded Livestock of the World 2007 dataset. For the HYDE data, 1-yr step values were obtained from the 10-yr step data by means of linear interpolation. Emission factors were derived from the work of Crutzen et al. (1986) and Lerner et al. (1988). Note that emission factors were specific to each livestock species but were assumed to be constant for a given species throughout the world. To account for estimation uncertainty, we conducted simulations using the upper- and lower-bound values of the emission factors.

\subsubsection{Emissions from termites}

$\mathrm{CH}_{4}$ emission from termites, which live in symbiosis with methanogenic protozoa in their guts, is a non-trivial source from the terrestrial biosphere. We estimated termite $\mathrm{CH}_{4}$ emissions by using the simple up-scaling method of Fung et al. (1991), in which biome-specific termite biomass density and emission factors were assumed. The average termite biomass densities were obtained from the work of Fraser et al. (1986): $5.6 \mathrm{~g} \mathrm{~m}^{-2}$ for tropical forests, $3.0 \mathrm{~g} \mathrm{~m}^{-2}$ for temperate forests, $4.5 \mathrm{~g} \mathrm{~m}^{-2}$ for savanna, and $7.8 \mathrm{~g} \mathrm{~m}^{-2}$ for cultivated land. We assumed that termites were absent in boreal forests. Emission factors were also obtained from the work of Fraser et al. (1986): they ranged from $1.0 \mathrm{mg} \mathrm{CH}_{4} \mathrm{~kg}$ termite ${ }^{-1} \mathrm{~h}^{-1}$ in deserts to $8.0 \mathrm{mg} \mathrm{CH}_{4}$ kg-termite ${ }^{-1} \mathrm{~h}^{-1}$ in savannas.

\subsection{Global simulation and analyses}

The VISIT simulations were conducted by using a $0.5^{\circ} \times 0.5^{\circ}$ grid mesh for the period from 1901 to 2009; we focus here on the outputs between 1960 and 2005. The simulations were driven by time-series data for atmospheric GHG concentrations, climate, and land-use changes. The historical time-series for atmospheric $\mathrm{CH}_{4}$ concentration was derived from ice-core and ground-based measurements (Etheridge et al., 1998; Robertson et al., 2001); it showed that the average $\mathrm{CH}_{4}$ concentration increased from $978 \mathrm{ppbv}$ in 1900 to $1227 \mathrm{ppbv}$ in 1960 and then to $1850 \mathrm{ppbv}$ in 2005 . Climate data (air temperature, cloudiness, precipitation, and humidity) for each grid cell were derived from the CRU TS3.1 dataset (Mitchell and Jones, 2005). Historical land cover (the fractions of cropland and pasture) was derived from Hurtt et al. (2006), who also provided a matrix of land-use change (e.g., gross conversion from primary forest to cropland). Soil properties (clay/sand composition and bulk density) were derived from a global dataset from the International Satellite Land Surface Climatology Project Initiative II (Hall et al., 2006). For each grid cell, a spin-up simulation was conducted for 300 to $4000 \mathrm{yr}$ under the atmospheric conditions that existed in 1900, until the simulation reached an equilibrium state for the net carbon budget. Note that dynamic feedback from the terrestrial biogeochemical cycle to the at- (a) Fraction of wetlands

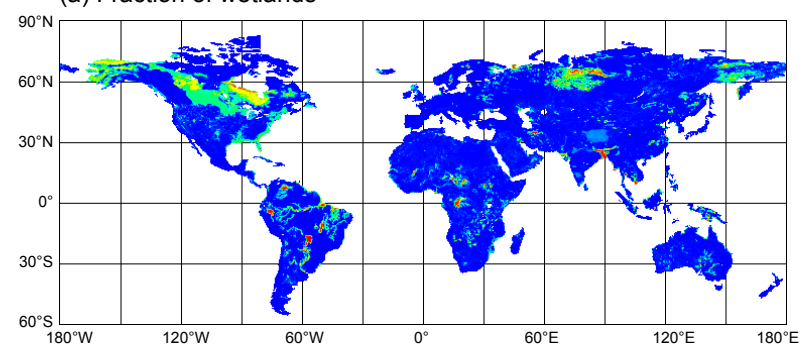

(b) Fraction of paddy fields

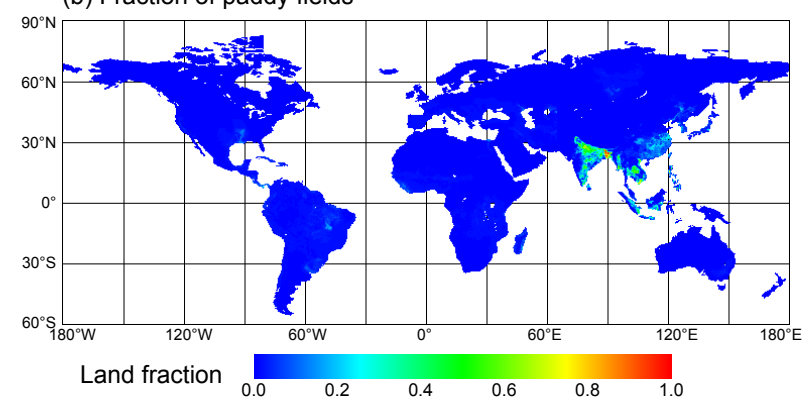

Fig. 2. Global maps of the distribution of (a) natural wetlands and (b) paddy fields that were used in the baseline simulation. The wetland extent was derived from the Global Lake and Wetland Database (Lehner and Döll, 2004), and the paddy field extent was derived from the MODIS-based estimation for Asia (Takeuchi and Yasuoka, 2006; $10^{\circ} \mathrm{S}$ to $50^{\circ} \mathrm{N}, 65^{\circ}$ to $150^{\circ} \mathrm{E}$ ) and data by Monfreda et al. (2008) for other areas.

mospheric GHG concentration and climate system was not considered; that is, we conducted an off-line experiment.

Uncertainty in the estimated terrestrial $\mathrm{CH}_{4}$ budget was evaluated on the basis of alternative calculations by using different assumptions and different estimation schemes.

Two datasets for the distribution of inundated wetlands were used (Fig. 2a): those of Matthews and Fung (1987) and Lehner and Döll (2004). When using the former dataset, the annual mean inundation fraction was used. In the latter case, the seasonal change in the inundated fraction was derived from satellite data (SSM/I; Prigent et al., 2007) and combined with the wetland map of Lehner and Döll (2004). For conducting long-term simulations, average distributions of inundated wetlands (i.e., no interannual variability) were used throughout the simulation period.

Two datasets of paddy field distribution were used (Fig. 2b): a global map produced by Monfreda et al. (2008) and the Monsoon Asia map produced by the Institute of Industrial Sciences, University of Tokyo (Takeuchi and Yasuoka, 2006). The former is based on statistical inventory data, and the latter is based on MODIS image analysis.

Two schemes of wetland and paddy field $\mathrm{CH}_{4}$ emission were used: those of Cao et al. (1996) and Walter and Heimann (2000). The scheme by Cao et al. (1996) was applied only to the wetlands from Lehner and Döll (2004), 
Table 1. Comparison of components of the global $\mathrm{CH}_{4}$ budget for terrestrial ecosystem $\left(\mathrm{Tg} \mathrm{CH}_{4} \mathrm{yr}^{-1}\right)$ between the different simulations in this study and estimates from previous studies.

\begin{tabular}{|c|c|c|c|c|c|c|c|c|c|c|c|}
\hline \multirow[b]{2}{*}{ Base year } & \multicolumn{4}{|c|}{ This study (mean \pm s.d. [IAV]) } & \multirow{2}{*}{$\begin{array}{r}\text { Hein et } \\
\text { al. (1997) } \\
1983-1989\end{array}$} & \multirow{2}{*}{$\begin{array}{r}\text { Wuebbles and } \\
\text { Hayhoe (2002) } \\
-\end{array}$} & \multirow{2}{*}{$\begin{array}{r}\text { Scheehle et } \\
\text { al. }(2002) \\
1990\end{array}$} & \multirow{2}{*}{$\begin{array}{r}\text { Wang et } \\
\text { al. (2004) } \\
1994\end{array}$} & \multirow{2}{*}{$\begin{array}{r}\text { Mikaloff Fletcher } \\
\text { et al. (2004) } \\
2004\end{array}$} & \multirow{2}{*}{$\begin{array}{r}\text { Chen and } \\
\text { Prinn (2005) } \\
1996-2001\end{array}$} & \multirow{2}{*}{$\begin{array}{r}\text { Patra et } \\
\text { al. }(2009) \\
2000\end{array}$} \\
\hline & 1996-2005 & & & & & & & & & & \\
\hline Sources & WH $(1)^{1}$ & WH $(2)^{1}$ & Cao $(1)^{1}$ & Cao $(2)^{1}$ & & & & & & & \\
\hline Wetlands & $169.6 \pm 6.4$ & $192.0 \pm 8.2$ & $172.5 \pm 4.6$ & & 231 & 100 & - & 176 & 231 & 145 & 153.3 \\
\hline \multirow[t]{2}{*}{ Paddy fields } & $44.9 \pm 1.0$ & $43.0 \pm 1.1$ & $38.2 \pm 1.4$ & $30.8 \pm 1.1$ & 83 & 60 & 31 & 57 & 54 & 112 & 39.4 \\
\hline & Low est. & High est. & & & & & & & & & \\
\hline Biomass burning & $15.8 \pm 1.8$ & $18.0 \pm 2.1$ & & & 43 & 52 & 14 & 41 & 88 & 43 & 59.8 \\
\hline Plant emission & $8.9 \pm 0.2$ & $15.4 \pm 0.4$ & & & - & - & - & - & - & - & - \\
\hline Livestock ruminants ${ }^{4}$ & $64.9 \pm 0.4$ & $95.2 \pm 0.6$ & & & 92 & 81 & 76 & 83 & 91 & $189^{2}$ & $119.3^{3}$ \\
\hline Termites & $14.7 \pm 0.01$ & $27.1 \pm 0.04$ & & & - & 20 & - & 20 & 29 & 23 & 20.5 \\
\hline Sink & Algorithm ${ }^{5}$ & & & & & & & & & & \\
\hline \multirow[t]{2}{*}{ Upland soil oxidation } & 1 & 2 & 3 & 4 & & & & & & & \\
\hline & $32.5 \pm 0.7$ & $35.1 \pm 0.9$ & $24.6 \pm 0.2$ & $33.3 \pm 0.8$ & 26 & 30 & - & 34 & 30 & - & - \\
\hline
\end{tabular}

${ }^{1}$ Using Walter-Heimann and Cao et al. schemes with (1) wetland map by Lehner and Döll (2004) and paddy field map by Monfreda et al. (2008) and (2) wetland map by Matthews and Fung (1987) and Asian paddie field map by Takeuchi and Yasuoka (2006).

2 Including emissions from landfills and wastes.

${ }^{3}$ Including anthropogenic fire emission.

${ }^{4}$ Estimation on the basis of inventory and geographical map data.

5 Algorithm 1: Potter et al. (1996), 2: Ridgwell et al. (1999), 3: Del Grosso et al. (2000), 4: Curry (2007).

resulting in three estimates for paddy fields and four estimates for natural wetlands.

Four schemes for $\mathrm{CH}_{4}$ oxidation in upland soils were used: those of Potter et al. (1996), Ridgwell et al. (1999), Del Grosso et al. (2000), and Curry (2007).

Two up-scaling schemes for plant aerobic $\mathrm{CH}_{4}$ emission by Kirschbaum et al. (2006) were used: a photosynthesisbased scheme and a biomass-based scheme. In addition, we considered the case of no plant emission (i.e., a third set of estimates), because a general consensus has not yet been reached over the significance of this process (e.g., Bloom et al., 2010).

Two sets of emission factors (i.e., lower-end and higherend values within the plausible range) from biomass burning were used for each biome.

Two sets of termite density and $\mathrm{CH}_{4}$ emission factors (similarly, lower-end and higher-end values) were used.

Two sets of livestock emission factors (similarly, lowerend and higher-end values) were used.

On the basis of this summary, we obtained 1152 different combinations of calculation methods and parameter values for the net terrestrial $\mathrm{CH}_{4}$ budget, assuming that each flow was independent. We expected that the distribution of the total budget produced by these simulations would reveal the range of estimation uncertainties caused by variability in the base data and evaluation schemes. Note that other potentially important sources of uncertainties such as parameter values and prognostic inundation estimation were not assessed in this study. To facilitate our analysis and discussion, we chose the following "baseline" estimation as the standard for comparison: the $\mathrm{CH}_{4}$ emission scheme of Walter and Heimann (2000), the oxidation scheme of Curry (2007), the wetland map by Lehner and Döll (2004), and the paddy field map of Monfreda et al. (2008). For other emissions, we chose the average of the lowest and highest emission factors in the baseline estimation.

\section{Results and discussion}

\subsection{Global annual budget}

We estimated components of the global terrestrial $\mathrm{CH}_{4}$ budget by using the model and inventory data; Table 1 summarizes the results. From 1996 to 2005, natural wetlands accounted for the largest terrestrial $\mathrm{CH}_{4}$ source, producing 170 to $192 \mathrm{Tg} \mathrm{CH}_{4} \mathrm{yr}^{-1}$ for the range of wetland data and emission calculation schemes that we considered; these values were within the range of values estimated in previous studies (Table 1). Paddy fields were also a considerable source, with values ranging from 31 to $45 \mathrm{Tg} \mathrm{CH}_{4} \mathrm{yr}^{-1}$. The paddy field emission was comparable to that in previous studies (Table 1) but slightly higher than a recent inventorybased estimate of $25.6 \mathrm{Tg} \mathrm{CH}_{4} \mathrm{yr}^{-1}$ in 2000 (Yan et al., 2009). Also, our estimates are comparable to a recent estimate of 34 to $67 \mathrm{Tg} \mathrm{CH}_{4} \mathrm{yr}^{-1}$ (Neef et al., 2010) that was constrained on the basis of historical observations of the stable isotope ratio of atmospheric $\mathrm{CH}_{4}$. The estimated $\mathrm{CH}_{4}$ emission from biomass burning, 16 to $18 \mathrm{Tg} \mathrm{CH}_{4} \mathrm{yr}^{-1}$, fell within the range of previous studies, but was close to the lower end of those values. Plant emissions ranged from 9 to $15 \mathrm{Tg} \mathrm{CH}_{4} \mathrm{yr}^{-1}$; this is lower than the value estimated by Keppler et al. (2006) but still represents a moderate source in vegetated areas. Through the inventory-based estimation, we found that livestock ruminants were the second-largest 


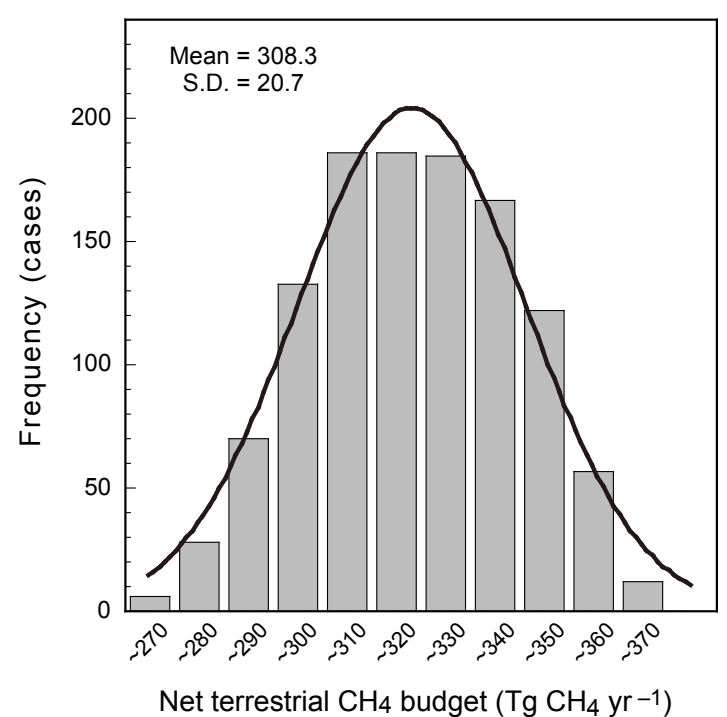

Fig. 3. Frequency distribution for the 1152 estimates of terrestrial $\mathrm{CH}_{4}$ budget (= wetland emission [4 estimates] + paddy field emission [3] + ruminant emission [2] + termite emission [2] + biomass burning emission [2] + plant aerobic emission $[3 ;=2$ estimates + null (no emission)] - oxidation in upland soils [4]) estimated by using different input data and parameterization schemes. Table 1 presents the detailed results of these simulations. The thick black line shows a normal distribution fitted to the data.

terrestrial $\mathrm{CH}_{4}$ source, with values ranging from 65 to $95 \mathrm{Tg} \mathrm{CH}_{4} \mathrm{yr}^{-1}$, and that termites were also a considerable source, with values ranging from 15 to $27 \mathrm{Tg} \mathrm{CH}_{4} \mathrm{yr}^{-1}$. Both sets of values were within the range of previous reports, although the lower value for termites was lower than the previously reported values. On the other hand, upland soils were estimated to act as a strong sink, with values ranging from 25 to $35 \mathrm{TgCH}_{4} \mathrm{yr}^{-1}$, depending on the oxidation estimation scheme that was chosen. Again, these values were within the range reported in previous studies. For example, Spahni et al. (2011) estimated global soil $\mathrm{CH}_{4}$ uptake as $28 \mathrm{Tg} \mathrm{CH}_{4} \mathrm{yr}^{-1}$ using the LPJ-WHyMe model; Riley et al. (2011) estimated uptake as $31 \mathrm{Tg} \mathrm{CH}_{4} \mathrm{yr}^{-1}$ using the CLM4Me model with the model's default parameters; and Neef et al. (2010) estimated uptake as 28 to $30 \mathrm{Tg} \mathrm{CH}_{4} \mathrm{yr}^{-1}$ on the basis of stable isotope analysis.

The estimated global $\mathrm{CH}_{4}$ budget was consistent with those in previous studies, with intermediate total source and sink values, 340 and $30 \mathrm{Tg} \mathrm{CH}_{4} \mathrm{yr}^{-1}$, respectively, obtained in this study. We plotted a frequency distribution for the estimated total $\mathrm{CH}_{4}$ budget (Fig. 3): the budget averaged 308.3 \pm $20.7 \mathrm{Tg} \mathrm{CH}_{4} \mathrm{yr}^{-1}$ (mean \pm standard deviation; min. 253 to max. $359 \mathrm{Tg} \mathrm{CH}_{4} \mathrm{yr}^{-1}$ ), excluding emissions from landfill, wastes, and wild animals, and anthropogenic combustion. A key uncertainty found in this study is associated with the available wetland and inundation maps, on the basis of estimates differed by more than $20 \mathrm{Tg} \mathrm{CH}_{4} \mathrm{yr}^{-1}$ (Table 1). This

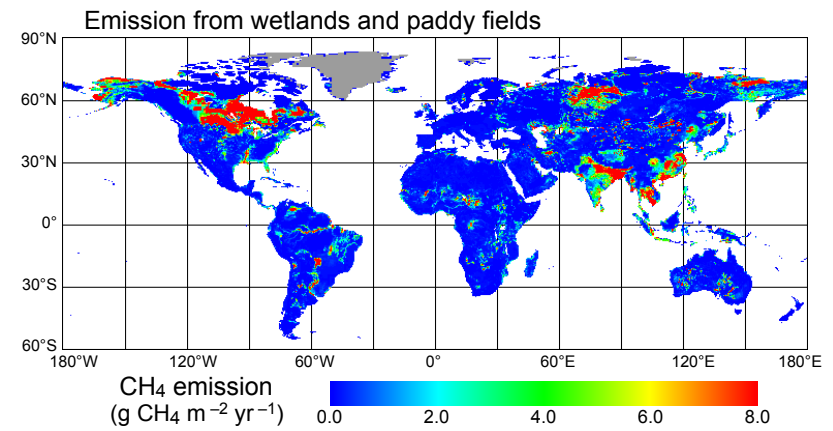

Fig. 4. Global map of the estimated $\mathrm{CH}_{4}$ emission from the wetlands and paddy fields shown in Fig. 2.

difference suggests that it is important to accurately delineate the locations of wetlands so that we can more accurately estimate their contribution to global $\mathrm{CH}_{4}$ emissions. This finding is consistent with those of a sensitivity analysis by Petrescu et al. (2010) using four wetland maps. In addition, the existence or absence of plant aerobic $\mathrm{CH}_{4}$ emissions affected the net budget, especially in densely vegetated areas; the mean value of $12.2 \mathrm{TgCH}_{4} \mathrm{yr}^{-1}$ was nearly $4 \%$ of the mean total budget (Fig. 3). However, the actual range of estimation uncertainty may be even larger, because the present study did not fully explore uncertainties in sensitive parameters values and predicted changes in wetland extent in response to global climate change, which can span a wide range (e.g., Riley et al., 2011). Furthermore, weighting of specific fluxes on the basis of agreement with observational data may refine the estimated probabilistic distribution of the terrestrial $\mathrm{CH}_{4}$ budget.

\subsection{Spatial pattern of sources and sinks}

As expected from the distribution of wetlands and paddy fields, northern wetlands (e.g., in North America and West Siberia) and Asian paddy fields were strong sources of $\mathrm{CH}_{4}$ with values as high as $8 \mathrm{gCH}_{4} \mathrm{~m}^{-2} \mathrm{yr}^{-1}$ (Fig. 4). Tropical wetlands and river flood plains (e.g., Amazonia, the Pantanal, and the Mississippi delta) were also substantial emission sources. High rates of emission from livestock ruminants (to a maximum of around $4 \mathrm{~g} \mathrm{CH}_{4} \mathrm{~m}^{-2} \mathrm{yr}^{-1}$ ) were found in parts of South Asia, East Asia, Europe, South America, and east Africa, where large numbers of livestock are raised (Fig. 5a). The $\mathrm{CH}_{4}$ sources from wetlands and livestock ruminants exhibited high spatial heterogeneity, with certain localized areas representing "hot spots". Emissions from termites occurred mainly in the subtropical areas of Australia, Africa, and South America (Fig. 5b). The maximum estimated areabased emission rate $\left(\sim 0.5 \mathrm{~g} \mathrm{CH}_{4} \mathrm{~m}^{-2} \mathrm{yr}^{-1}\right)$ was low compared with wetland and livestock ruminant emissions $(<10 \%$ of the corresponding maxima), but the wide area of termite habitat caused termites to be a substantial net $\mathrm{CH}_{4}$ source. 


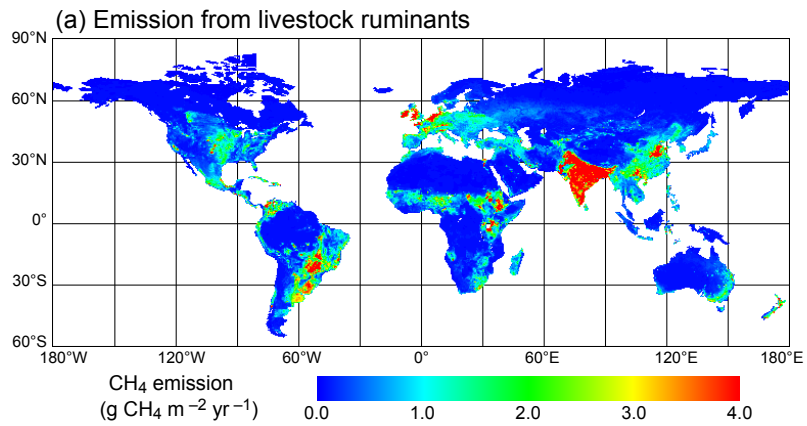

(b) Emission from termites

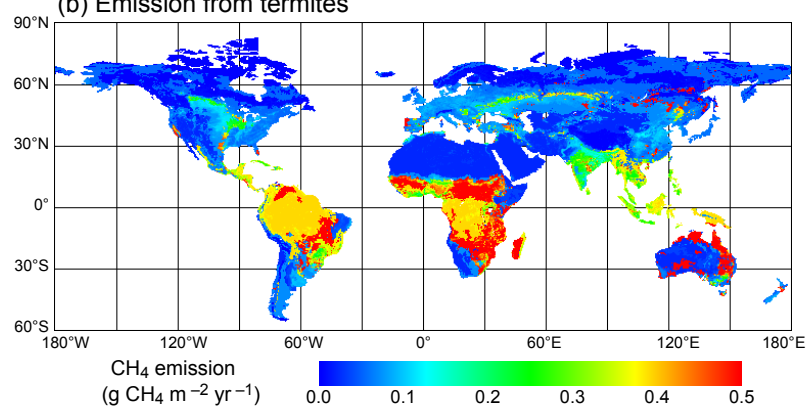

Fig. 5. Global maps of the estimated $\mathrm{CH}_{4}$ emission from (a) livestock ruminants (water buffalo, cattle, goats, pigs, and sheep) and (b) termites.

In terms of upland soil oxidation, the four schemes estimated comparable total uptakes ( 25 to $35 \mathrm{Tg} \mathrm{CH}_{4} \mathrm{yr}^{-1}$; Table 1), but with different spatial distributions. Potter et al.'s (1996) scheme estimated higher oxidation rates in tropical and temperate regions, but with weaker overall geographical contrasts (Fig. 6a). Ridgwell et al.'s (1999) scheme estimated higher rates in tropical and subtropical areas, including in several dry regions (e.g., Middle East, Central America, South America, and Australia; Fig. 6b). In this case, latitudinal contrasts were stronger. Del Grosso et al.'s (2000) scheme estimated clear contrasts between deciduous forests and other types of ecosystems (Fig. 6c), because it assumed that the thick litter layer at the surfaces of deciduous forests would have higher $\mathrm{CH}_{4}$ oxidation capacity. Correspondingly, arid regions, which typically have a thinner litter layer, showed lower oxidation rates. Curry's (2007) scheme produced results similar to those of Ridgwell et al. (because it is a revised version of their scheme), but revealed clearer contrasts between humid and dry ecosystems (Fig. 6d).

\subsection{Temporal variability}

Seasonal changes in the terrestrial $\mathrm{CH}_{4}$ budget were most evident at northern latitudes $\left(42^{\circ} \mathrm{N}\right.$ to $68^{\circ} \mathrm{N}$; Fig. 7 for the baseline simulation), where a vast area of northern wetland actively emits $\mathrm{CH}_{4}$ during the summer growing period. At lower latitudes, tropical wetlands and paddy fields made these areas a net $\mathrm{CH}_{4}$ source throughout the year. At other latitudes, small net sinks occurred as a result of upland oxidation, except where emissions from termites and livestock ruminants were significant (Fig. 5).

The global terrestrial $\mathrm{CH}_{4}$ budget and its components changed from 1900 to the present (Fig. 8 for the baseline simulation). Wetland and paddy field emissions were affected by meteorological conditions, leading to stochastic interannual variability (IAV). Because of expansion of the area covered by paddy fields in Asia, paddy field emissions increased from $24 \mathrm{Tg} \mathrm{CH}_{4} \mathrm{yr}^{-1}$ in the early 1900 s to $45 \mathrm{Tg} \mathrm{CH}_{4} \mathrm{yr}^{-1}$ in the 2000s. Note that fertilizer applications in paddy fields, which may decrease $\mathrm{CH}_{4}$ emission (Kai et al., 2011), were not fully accounted for in the present study. Emission from livestock ruminants increased from $35 \mathrm{Tg} \mathrm{CH}_{4} \mathrm{yr}^{-1}$ in the early 1900 s to $80 \mathrm{Tg} \mathrm{CH}_{4} \mathrm{yr}^{-1}$ in the 2000 s; this inventory-based estimate contains little stochastic variability because it depends on human, rather than environmental, factors. Among livestock, the temporal increment was largely attributable to increased cattle emission, from $22 \mathrm{Tg} \mathrm{CH}_{4} \mathrm{yr}^{-1}$ in the early 1900 s to $60 \mathrm{Tg} \mathrm{CH}_{4} \mathrm{yr}^{-1}$ in the 2000s. In contrast, emission from water buffalo peaked at $14 \mathrm{Tg} \mathrm{CH}_{4} \mathrm{yr}^{-1}$ in the $1950 \mathrm{~s}$ and declined to $8 \mathrm{Tg} \mathrm{CH}_{4} \mathrm{yr}^{-1}$ in the 2000s. The estimated termite emission, using either the high or low emission factors, slowly decreased to less than $1 \mathrm{Tg} \mathrm{CH}_{4} \mathrm{yr}^{-1}$ during the experimental period as a result of land-use conversion from natural vegetation to cropland or pasture. Plant aerobic emission increased gradually in parallel with increased photosynthetic productivity and leaf mass as a result of the $\mathrm{CO}_{2}$ fertilization effect. Biomass burning emission showed substantial IAV due to variations in fuel and moisture conditions, but it did not show a clear linear trend. $\mathrm{CH}_{4}$ oxidation by upland soils increased, mainly as a result of the increased $\mathrm{CH}_{4}$ gradient between the atmosphere and the soil air space that resulted from using Curry's (2007) scheme.

The global relationship between annual mean temperature and terrestrial net $\mathrm{CH}_{4}$ exchange (Fig. 9 for the baseline simulation) showed a significant weak to moderately strong linear relationship $\left(R^{2}=0.38, P<0.01\right)$. On the basis of the results of this regression, net terrestrial $\mathrm{CH}_{4}$ emission has increased at a rate of $41.6 \mathrm{Tg} \mathrm{CH}_{4} \mathrm{yr}^{-1}$ per $1{ }^{\circ} \mathrm{C}$ of warming, suggesting the existence of a positive biogeochemical feedback in response to climatic warming (and partly in response to historical land-use change in parallel with temperature change). On the basis of the 100-yr Global Warming Potential for $\mathrm{CH}_{4}$ ( $=25$; IPCC, 2007), this responsiveness of the $\mathrm{CH}_{4}$ budget corresponded to an increase of $283 \mathrm{Tg} \mathrm{C} \mathrm{yr}^{-1}$ in the climate-carbon $\left(\mathrm{CO}_{2}\right)$ cycle feedback. As implied by a study using an Earth System model (Gedney et al., 2004), the interaction between climate and the methane cycle can exert a positive feedback as a result of human-induced climate change. The feedback would be accelerated by additional emissions from permafrost melting and methane hydrates (O'Connor et al., 2010). 

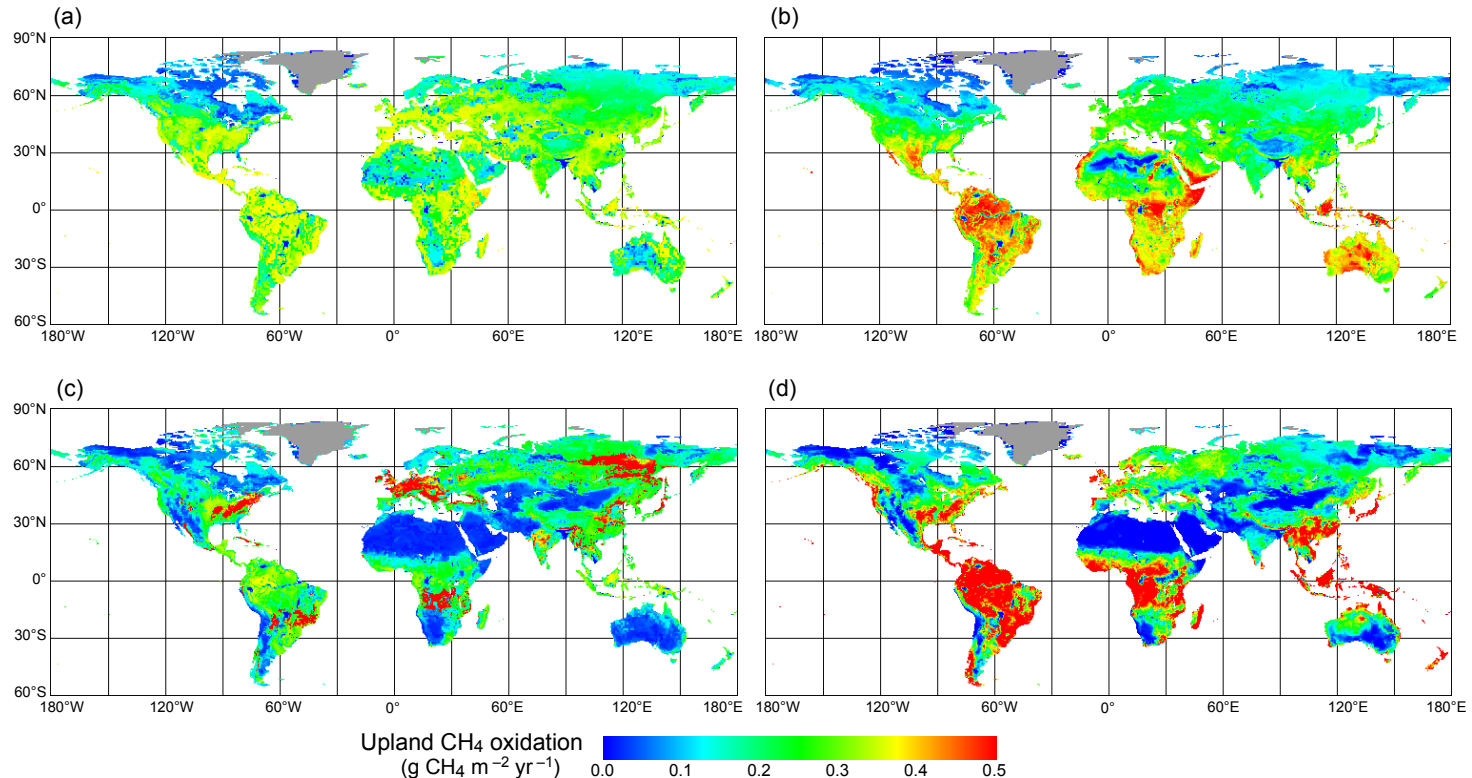

Fig. 6. Global maps of the estimated rates of $\mathrm{CH}_{4}$ oxidation by upland soils using different calculation methods and parameterizations: (a) Potter et al. (1996), (b) Ridgwell et al. (1999), (c) Del Grosso et al. (2000), and (d) Curry (2007). Note that the same data were used for soil water content and temperature in each of the four simulations.

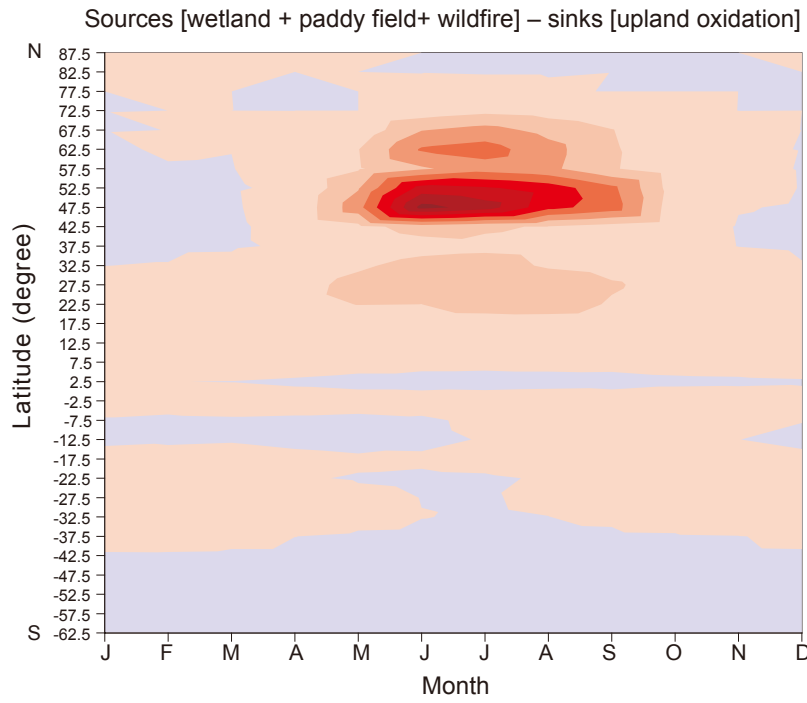

Net $\mathrm{CH}_{4}$ budget $\left(\mathrm{Tg} \mathrm{CH}_{4} 5^{\circ}\right.$-zone mon-1)

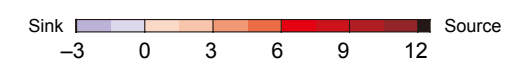

Fig. 7. Seasonal and latitudinal distribution of the terrestrial $\mathrm{CH}_{4}$ budget (= wetland emission + paddy field emission + biomass burning emission - upland soil oxidation) in the baseline experiment (1996-2005).

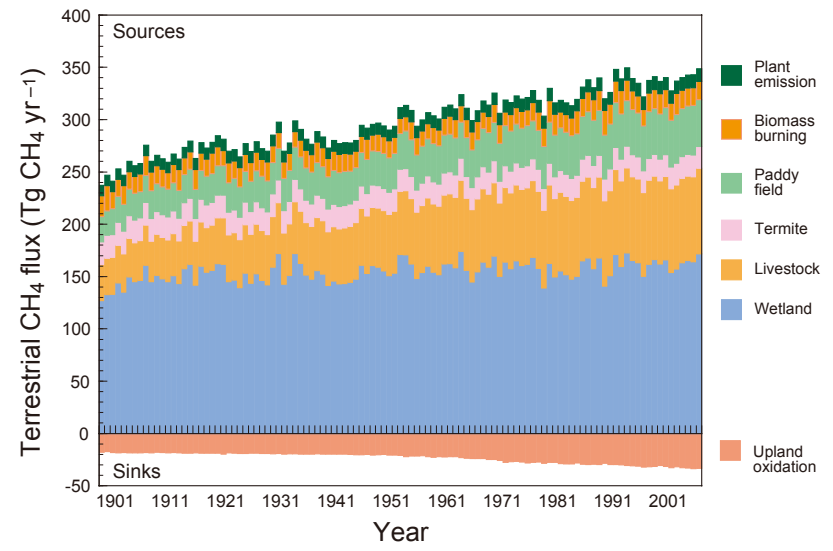

Fig. 8. Temporal changes in the estimated terrestrial $\mathrm{CH}_{4}$ budget components in the baseline experiment.

\section{Conclusions}

In this study, we simulated the global terrestrial $\mathrm{CH}_{4}$ budget by using the VISIT model, and we accounted for uncertainties among the different estimation and parameterization schemes; the result was a mean net emission of $308 \pm 21 \mathrm{Tg} \mathrm{CH}_{4} \mathrm{yr}^{-1}$. The coefficient of variation (the standard deviation divided by the mean), $6.7 \%$, was smaller than that of the global $\mathrm{CO}_{2}$ budget, which equaled $15 \%$ in a recent meta-analysis of net primary production (Ito, 


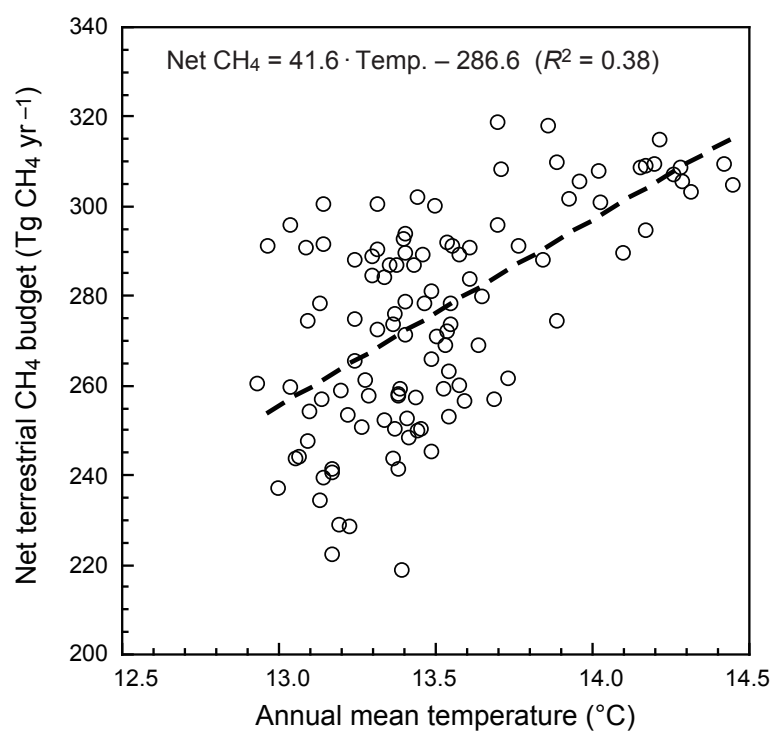

Fig. 9. Relationship between annual global mean land temperature and estimated net terrestrial $\mathrm{CH}_{4}$ budget in the baseline simulation.

2011). The estimated flows and the total budget were both comparable to the results of previous studies based on inventories, biogeochemical models, and atmospheric inversion models (Table 1). The contemporary natural source value of $220 \mathrm{Tg} \mathrm{CH}_{4} \mathrm{yr}^{-1}$ in our study was comparable to the range of 145 to $260 \mathrm{Tg} \mathrm{CH}_{4} \mathrm{yr}^{-1}$ in previous studies (IPCC, 2007). However, it should be noted that several sources were not accounted for in our study, namely emissions from wastes and landfills, mining, wild ruminants, and anthropogenic combustion. Modeling these ancillary sources is difficult, so an alternative inventory-based appraisal would be required. In terms of the estimation uncertainty, additional differences among estimates could be produced by using different climate datasets (e.g., Ito and Sasai, 2006).

We simulated the global terrestrial $\mathrm{CH}_{4}$ budget to discuss the unique roles of various components of the terrestrial biosphere in determining the global budget. The spatial pattern and temporal variability of the simulated $\mathrm{CH}_{4}$ fluxes have implications for efforts to interpret the characteristic variability in these studies. Figure 10 presents the estimated anomaly in the terrestrial $\mathrm{CH}_{4}$ budget (compared with the baseline simulation in Fig. 8), which represents the deviation of the value in a given year compared with the 1981-2000 average value, and compares this anomaly with the atmospheric $\mathrm{CH}_{4}$ growth rate at the Mauna Loa and South Pole observatories monitored by the US National Oceanic and Atmospheric Administration (Dlugokencky et al., 1994, 2011). It is apparent that the amplitude of interannual variability in the estimated net terrestrial $\mathrm{CH}_{4}$ budget was smaller than that in the observed atmospheric $\mathrm{CH}_{4}$ accumulation, and that the variations in the terrestrial budget therefore might not fully ex-

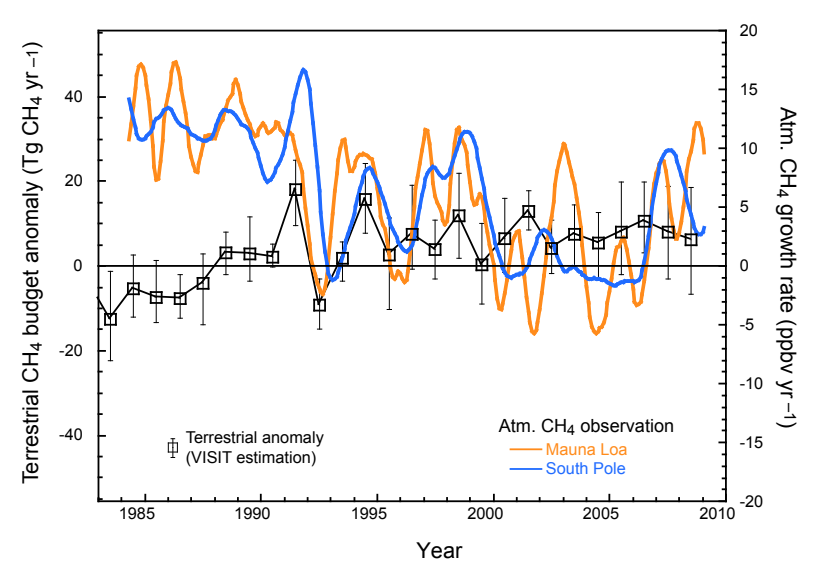

Fig. 10. Temporal change in the anomalies (defined as the deviation from the 1981-2000 average value, represented by the horizontal line at 0 ) in the annual global terrestrial $\mathrm{CH}_{4}$ budget estimated by using the VISIT model and inventory data. Values represent the means and the minimum-maximum range in the 1152 estimates based on the different combinations of input data and different calculation and parameterization schemes. The orange and light blue lines show the changes in atmospheric $\mathrm{CH}_{4}$ at the Mauna Loa and South Pole observatories (data from the NOAA/ESRL/GMD dataset; Dlugokencky et al., 1994, 2011). Note: $1 \mathrm{ppbv}=2.123 \mathrm{Tg} \mathrm{CH}_{4}-\mathrm{C}$.

plain the decrease in the $\mathrm{CH}_{4}$ increment that was observed from the 1990s to the 2000s (Bousquet et al., 2006; Dlugokencky et al., 2011). This suggests that other factors such as temporal variability in inundated areas, chemical reactions in the atmosphere, anthropogenic emissions, and tropospherestratosphere exchanges may contribute substantially to the temporal variability in the atmospheric $\mathrm{CH}_{4}$ accumulation rate. For example, Kai et al. (2011) suggested that decreased $\mathrm{CH}_{4}$ emission from paddy fields due to fertilizer application accounted for about half of the slowdown of atmospheric $\mathrm{CH}_{4}$ accumulation. In contrast, Hodson et al. (2011) suggested that repeated El Niño events during this period were a contributing factor to the stabilization of atmospheric $\mathrm{CH}_{4}$, suggesting that further investigations will be required to establish an overview of the decadal-scale $\mathrm{CH}_{4}$ variation. On the other hand, several anomalies in the estimated terrestrial budget coincided with atmospheric anomalies (e.g., a rapid deceleration in the growth rate of $\mathrm{CH}_{4}$ in 1992 and an acceleration in 1998), suggesting dominant impacts by the terrestrial biosphere during some periods.

It is difficult to constrain and validate large-scale models because observation-based estimates of $\mathrm{CH}_{4}$ emissions at these scales are very uncertain. Indeed, the model used in this study has been compared only with a limited number of chamber measurements (e.g., Inatomi et al., 2010). Recent progress in micrometeorological techniques has enabled $\mathrm{CH}_{4}$ flux measurement at an ecosystem scale using 
the eddy-covariance method (McDermitt et al., 2011). Although there remain several methodological difficulties with this method (e.g., correcting for atmospheric stability and advection), this new methodology will enable us to use more data to constrain biogeochemical models and reduce estimation uncertainty. In parallel, appropriate up-scaling algorithms from a point to a regional scale should be developed, because spatial heterogeneity in $\mathrm{CH}_{4}$-related processes such as wetland hydrology, animal distribution, and fire regime, should affect broad-scale evaluations of $\mathrm{CH}_{4}$ budget, even using process-based models.

Furthermore, recent satellite remote-sensing methods may soon permit measurements of atmospheric $\mathrm{CH}_{4}$ at a global scale. For example, the SCIAMACHY sensor on the ENVISAT satellite is being used to observe atmospheric trace gases, including $\mathrm{CH}_{4}$, and the data are being used as inputs for atmospheric inversion models to estimate surface fluxes (Bergamaschi et al., 2009). More and more satellite data will be available to estimate the global $\mathrm{CH}_{4}$ budget, including those from Japan's Greenhouse gas Observing SATellite (GOSAT; Yoshida et al., 2011). In the near future, model-based estimates such as those described in this paper, will be compared with satellite observations for validation. Because the top-down approach observes total surface exchange, including not only land ecosystem fluxes but also anthropogenic and freshwater sources (Bastviken et al., 2011), separation pf the overall values into specific components becomes another issue. Recent progress in measurement of the stable isotope ratios in atmospheric $\mathrm{CH}_{4}$ (e.g., Lassey et al., 2011) and data-model fusion with the goal of optimizing estimates (e.g., Neef et al., 2010; Riley et al., 2011) may allow more precise assessments of each flux. Also, crosscomparison of model-estimated surface fluxes with atmospheric transport models (e.g., TransCom- $\mathrm{CH}_{4}$ by Patra et al., 2011) would effectively reveal the accuracy and uncertainty in the present global $\mathrm{CH}_{4}$ budget. As more and better data become available, model studies will become an increasingly important tool for analyzing the mechanisms underlying the global budget and for predicting future budgets under climate change.

Acknowledgements. This study was supported by Grants-in-Aid for Scientific Research (No. 19310017) from the Japan Society for the Promotion of Science and (No. 21114010) from the Ministry of Education, Culture, Sports, Science and Technology.

Edited by: D. Fernández Prieto

\section{References}

Andreae, M. O. and Merlet, P.: Emission of trace gases and aerosols from biomass burning, Global Biogeochem. Cy., 15, 955-966, 2001.

Arneth, A., Harrison, S. P., Zaehle, S., Tsigaridis, K., Menon, S., Bartlein, P. J., Feichter, J., Korhola, A., Kulmala, M., O’Donnell, D., Schurgers, G., Sorvari, S., and Vesala, T.: Terrestrial biogeochemical feedbacks in the climate system, Nature Geosci., 3, 525-532, 2010.

Bastviken, D., Tranvik, L. J., Downing, J. A., Crill, P. M., and Enrich-Prast, A.: Freshwater methane emissions offset the continental carbon sink, Science, 331, 50, 2011.

Bergamaschi, P., Frankenberg, C., Meirink, J. F., Krol, M., Villani, M. G., Houweling, S., Dentener, F., Dlugokencky, E. J., Miller, J. B., Gatti, L. V., Engel, A., and Levin, I.: Inverse modeling of global and regional $\mathrm{CH}_{4}$ emissions using SCIAMACHY satellite retrievals, J. Geophys. Res., 114, D22301, doi:10.1029/2009JD012287, 2009.

Bloom, A. A., Lee-Taylor, J., Madronich, S., Messenger, D. J., Palmer, P. I., Reay, D. S., and McLeod, A. R.: Global methane emission estimates from ultraviolet irradiation of terrestrial plant foliage, New Phytol., 187, 417-425, 2010.

Bousquet, P., Ciais, P., Miller, J. B., Dlugokencky, E. J., Hauglustaine, D. A., Prigent, C., van der Werf, G. R., Peylin, P., Brunke, E.-G., Carouge, C., Langenfelds, R. L., Lathière, J., Papa, F., Ramonet, M., Schmidt, M., Steele, L. P., Tyler, S. C., and White, J.: Contribution of anthropogenic and natural sources to atmospheric methane variability, Nature, 439-443, 2006.

Cao, M., Marshall, S., and Gregson, K.: Global carbon exchange and methane emissions from natural wetlands: Application of a process-based model, J. Geophys. Res., 101, 14399-14414, 1996.

Chen, Y.-H. and Prinn, R. G.: Atmospheric modeling of highand low-frequency methane observations: Importance of interannually varying transport, J. Geophys. Res., 110, D10303, doi:10.1029/2004JD005542, 2005.

Christensen, T. R. and Cox, P.: Response of methane emission from arctic tundra to climatic change: Results from a model simulation, Tellus, 47B, 301-309, 1995.

Crutzen, P. J., Aselmann, I., and Seiler, W.: Methane production by domestic animals, wild ruminants, other herbivorous fauna, and humans, Tellus, 38B, 271-284, 1986.

Curry, C. L.: Modeling the soil consumption of atmospheric methane at the global scale, Global Biogeochem. Cy., 21, GB4012, doi:10.1029/2006GB002818, 2007.

Del Grosso, S. J., Parton, W. J., Mosier, A. R., Ojima, D. S., Potter, C. S., Borken, W., Brumme, R., Butterbach-Bahl, K., Crill, P. M., Dobbie, K., and Smith, K. A.: General $\mathrm{CH}_{4}$ oxidation model and comparisons of $\mathrm{CH}_{4}$ oxidation in natural and managed systems, Global Biogeochem. Cy., 14, 999-1019, 2000.

Dlugokencky, E. J., Masaire, K. A., Lang, P. M., Tans, P. P., Steele, L. P., and Nisbet, E. G.: A dramatic decrease in the growth rate of atmospheric methane in the northern hemisphere during 1992, Geophys. Res. Lett., 21, 45-48, 1994.

Dlugokencky, E. J., Nisbet, E. G., Fisher, R., and Lowry, D.: Global atmospheric methane: budget, changes and dangers, Phil. Trans. Roy. Soc., A369, 2058-2072, 2011.

Etheridge, D. M., Steele, L. P., Francey, R. J., and Langenfelds, R. L.: Atmospheric methane between 1000 A.D. and present: 
Evidence of anthropogenic emissions and climatic variability, J. Geophys. Res., 103, 15979-15993, 1998.

Fraser, P. J., Rasmussen, R. A., Creffield, J. W., French, J. R., and Khalil, M. A. K.: Termites and global methane - another assessment, J. Atmos. Chem., 4, 295-310, 1986.

Fung, I., John, J., Lerner, J., Matthews, E., Prather, M., Steele, L. P., and Fraser, P. J.: Three-dimensional model synthesis of the global methane cycle, J. Geophys. Res., 96, 13033-13065, 1991.

Gedney, N., Cox, P. M., and Huntingford, C.: Climate feedback from wetland methane emissions, Geophys. Res. Lett., 31, L20503, doi:10.1029/2004GL020919, 2004.

Hall, F. G., de Colstoun, E. B., Collatz, G. J., Landis, D., Dirmeyer, P., Betts, A., Huffman, G. J., Bounoua, L., and Meeson, B.: ISLSCP Initiative II global data sets: Surface boundary conditions and atmospheric forcings for land-atmosphere studies, J. Geophys. Res., 111, D22S01, doi:10.1029/2006JD007366, 2006.

Hazarika, M., Yasuoka, Y., Ito, A., and Dye, D. G.: Estimation of net primary productivity by integrating remote sensing with an ecosystem model, Remote Sens. Environ., 94, 298-310, 2005.

Hein, R., Crutzen, P. J., and Heimann, M.: An inverse modeling approach to investigate the global atmospheric methane cycle, Global Biogeochem. Cy., 11, 43-76, 1997.

Hodson, E. L., Poulter, B., Zimmermann, N. E., Prigent, C., and Kaplan, J. O.: The El Niño-Southern Oscillation and wetland methane interannual variability, Geophys. Res. Lett., 38, L08810, doi:10.1029/2011GL046861, 2011.

Hurtt, G. C., Frolking, S., Fearon, M. G., Moore, B., Shevliakova, E., Malyshev, S., Pacala, S. W., and Houghton, R. A.: The underpinnings of land-use history: three centuries of global gridded land-use transitions, wood-harvest activity, and resulting secondary lands, Global Change Biol., 12, 1-22, 2006.

Inatomi, M., Ito, A., Ishijima, K., and Murayama, S.: Greenhouse gas budget of a cool temperate deciduous broadleaved forest in Japan estimated with a process-based model, Ecosystems, 13, 472-483, 2010.

Intergovernmental Panel on Climate Change (IPCC): Climate Change 2007: The Physical Science Basis, edited by: Solomon, S., Qin, D., Manning, M., Marquis, M., Averyt, K., Tignor, M. M. B., Miller, H. L. J., and Chen, Z., Cambridge University Press, Cambridge, 996 pp., 2007.

Ito, A.: Climate-related uncertainties in projections of the 21 st century terrestrial carbon budget: Off-line model experiments using IPCC greenhouse gas scenarios and AOGCM climate projections, Clim. Dynam., 24, 435-448, 2005.

Ito, A.: The regional carbon budget of East Asia simulated with a terrestrial ecosystem model and validated using AsiaFlux data, Agr. For. Meteorol., 148, 738-747, 2008.

Ito, A.: Evaluation of defoliation impacts of tropical cyclones on the forest carbon budget using flux data and a process-based model, J. Geophys. Res., 115, G04013, doi:10.1029/2010JG001314, 2010.

Ito, A.: A historical meta-analysis of global terrestrial net primary productivity: Are estimates converging?, Global Change Biol., 17, 3161-3175, doi:10.1111/j.1365-2486.2011.02450.x, 2011.

Ito, A. and Oikawa, T.: A model analysis of the relationship between climate perturbations and carbon budget anomalies in global terrestrial ecosystems: 1970-1997, Clim. Res., 15, 161183,2000 .
Ito, A. and Oikawa, T.: A simulation model of the carbon cycle in land ecosystems (Sim-CYCLE): A description based on drymatter production theory and plot-scale validation, Ecol. Model., 151, 147-179, 2002.

Ito, A. and Sasai, T.: A comparison of simulation results from two terrestrial carbon cycle models using three climate datasets, Tellus, 58B, 513-522, 2006.

Kai, F. M., Tyler, S. C., Randerson, J. T., and Blake, D. R.: Reduced methane growth rate explained by decreased Northern Hemisphere microbial sources, Nature, 476, 194-197, 2011.

Kato, T., Ito, A., and Kawamiya, M.: Multiple temporal scale variability during the twentieth century in global carbon dynamics simulated by a coupled climate-terrestrial carbon cycle model, Clim. Dynam., 32, 901-923, 2009.

Keppler, F., Hamilton, J. T. G., Braß, M., and Röckmann, T.: Methane emissions from terrestrial plants under aerobic conditions, Nature, 439, 187-191, 2006.

Kirschbaum, M. U. F., Bruhn, D., Etheridge, D. M., Evans, J. R., Farquhar, G. D., Gifford, R. M., Paul, K. I., and Winters, A. J.: A comment on the quantitative significance of aerobic methane release by plants, Func. Plant Biol., 33, 521-530, 2006.

Klein Goldewijk, K., Beusen, A., Van Drecht, G., and de Vos, M.: The HYDE 3.1 spatially explicit database of human-induced global land-use change over the past 12,000 years, Global Ecol. Biogeogr., 20, 73-86, 2011.

Lassey, K. R., Allan, W., and Mikaloff Fletcher, S. E.: Seasonal inter-relationships in atmospheric methane and companion $\delta^{13} \mathrm{C}$ values: effects of sinks and sources, Tellus, 63B, 287-301, 2011.

Lehner, B. and Döll, P.: Development and validation of a global database of lakes, reservoirs and wetlands, J. Hydrol., 296, 1-22, 2004.

Lerner, J., Matthews, E., and Fung, I.: Methane emission from animals: a global high-resolution data base, Global Biogeochem. Cy., 2, 139-156, 1988.

Martinson, G. O., Werner, F. A., Scherber, C., Conrad, R., Corre, M. D., Flessa, H., Wolf, K., Klose, M., Gradstein, S. R., and Veldkamp, E.: Methane emission from tank bromeliads in neotropical forests, Nature Geosci., 3, 766-769, 2010.

Matthews, E. and Fung, I.: Methane emission from natural wetlands: Global distribution, area, and environmental characteristics of sources, Global Biogeochem. Cy., 1, 61-86, 1987.

McDermitt, D., Burba, G., Xu, L., Anderson, T., Komissarov, A., Reinsche, B., Schedlbauer, J., Starr, G., Zona, D., Oechel, W., Oberbauer, S., and Hastings, S.: A new low-power, open-path instrument for measuring methane flux by eddy covariance, Appl. Phys. B, 102, 391-405, 2011.

Mikaloff Fletcher, S. E., Tans, P. P., Bruhwiler, L. M., Miller, J. B., and Heimann, M.: $\mathrm{CH}_{4}$ sources estimated from atmospheric observations of $\mathrm{CH}_{4}$ and its ${ }^{13} \mathrm{C} /{ }^{12} \mathrm{C}$ isotopic ratios: 1 . Inverse modeling of source processes, Global Biogeochem. Cy., 18, GB4004, doi:10.1029/2004GB002223, 2004.

Mitchell, T. D. and Jones, P. D.: An improved method of constructing a database of monthly climate observations and associated high-resolution grids, Int. J. Climatol., 25, 693-712, 2005.

Monfreda, C., Ramankutty, N., and Foley, J. A.: Farming the planet: 2. Geographic distribution of crop areas, yields, physiological types, and net primary production in the year 2000, Global Biogeochem. Cy., 22, GB1022, doi:10.1029/2007GB002947, 2008.

Neef, L., van Weele, M., and van Velthoven, P.: Optimal estimation 
of the present-day global methane budget, Global Biogeochem. Cy., 24, GB4024, doi:10.1029/2009GB003661, 2010.

O'Connor, F. M., Boucher, O., Gedney, N., Jones, C. D., Folberth, G. A., Coppell, R., Friedlingstein, P., Collins, W. J., Chappellaz, J., Ridley, J., and Johnson, C. E.: Possible role of wetlands, permafrost, and methane hydrates in the methane cycle under future climate change: a review, Rev. Geophys., 48, RG4005, doi:10.1029/2010RG000326, 2010.

Patra, P. K., Takigawa, M., Ishijima, K., Choi, B.-C., Cunnold, D., Dlugokencky, E. J., Fraser, P., Gomez-Pelaez, A. J., Goo, T.-Y., Kim, J.-S., Krummel, P., Langenfelds, R., Meinhardt, F., Mukai, H., O'Doherty, S., Prinn, R. G., Simmonds, P., Steele, P., Tohjima, Y., Tsuboi, K., Uhse, K., Weiss, R., Worthy, D., and Nakazawa, T.: Growth rate, seasonal, synoptic, diurnal variations and budget of methane in the lower atmosphere, J. Meteorol. Soc. Jpn, 87, 635-663, 2009.

Patra, P. K., Houwelling, S., Krol, M., Bousquet, P., Belikov, D., Bergmann, D., Bian, H., Cameron-Smith, P., Chipperfield, M. P., Corbin, K., Fortems-Cheiney, A., Fraser, A., Gloor, E., Hess, P., Ito, A., Kawa, S. R., Law, R. M., Loh, Z., Maksyutov, S., Meng, L., Palmer, P. I., Prinn, R. G., Rigby, M., Saito, R., and Wilson, C.: TransCom model simulations of $\mathrm{CH}_{4}$ and related species: linking transport, surface flux and chemical loss with $\mathrm{CH}_{4}$ variability in the troposphere and lower stratosphere, Atmos. Chem. Phys., 11, 12813-12837, 2011,

http://www.atmos-chem-phys.net/11/12813/2011/.

Petrescu, A. M. R., van Beek, L. P. H., van Huissteden, J., Prigent, C., Sachs, T., Corradai, C. A. R., Parmenter, F. J. W., and Dolman, A. J.: Modeling regional to global $\mathrm{CH}_{4}$ emissions of boreal and arctic wetlands, Global Biogeochem. Cy., 24, GB4009, doi:10.1029/2009GB003610, 2010.

Potter, C. S., Davidson, E. A., and Verchot, L. V.: Estimation of global biogeochemical controls and seasonality in soil methane consumption, Chemosphere, 32, 2219-2246, 1996.

Prigent, C., Papa, F., Aires, F., Rossow, W. B., and Matthews, E.: Global inundation dynamics inferred from multiple satellite observations, 1993-2000, J. Geophys. Res., 112, D12107, doi:10.1029/2006JD007847, 2007.

Ridgwell, A. J., Marshall, S. J., and Gregson, K.: Consumption of atmospheric methane by soils: A process-based model, Global Biogeochem. Cy., 13, 59-70, 1999.

Riley, W. J., Subin, Z. M., Lawrence, D. M., Swenson, S. C., Torn, M. S., Meng, L., Mahowald, N. M., and Hess, P.: Barriers to predicting changes in global terrestrial methane fluxes: analyses using CLM4Me, a methane biogeochemistry model integrated in CESM, Biogeosciences, 8, 1925-1953, doi:10.5194/bg-8-19252011, 2011.

Ringeval, B., de Noblet-Ducoudré, N., Ciais, P., Bousquet, P., Prigent, C., Papa, F., and Rossow, W. B.: An attempt to quantify the impact of changes in wetland extent on methane emissions on the seasonal and interannual time scales, Global Biogeochem. Cy., 24, GB2003, doi:10.1029/2008GB003354, 2010.

Robertson, A., Overpeck, J., Rind, D., Mosley-Thompson, E., Zielinski, G., Lean, J., Koch, D., Penner, J., Tegen, I., and Healy, R.: Hypothesized climate forcing time series for the last 500 years, J. Geophys. Res., 106, 14783-14803, 2001.

Saito, M., Ito, A., and Maksyutov, S.: Evaluation of biases in JRA25/JCDAS precipitation and their impact on the global terrestrial carbon balance, J. Climate, 24, 4109-4125, 2011.
Sasakawa, M., Ito, A., Machida, T., Tsuda, N., Niwa, Y., Davydov, D., Fofonov, A., and Arshinov, M.: Annual variation of methane emissions from forested bogs in West Siberia (20052009): a case of high $\mathrm{CH}_{4}$ and precipitation rate in the summer of 2007, Atmos. Chem. Phys. Discuss., 10, 27759-27776, doi:10.5194/acpd-10-27759-2010, 2010.

Saxton, K. E., Rawls, W. J., Romberger, J. S., and Papendick, R. I.: Estimating generalized soil-water characteristics from texture, Soil Sci. Soc. Am. J., 50, 1031-1036, 1986.

Scheehle, B. R., Irving, W. N., and Kruger, D.: Global anthropogenic methane emission, in: Non- $\mathrm{CO}_{2}$ Greenhouse Gases, edited by: Van Ham, J., Baede, A. P., Guicherit, R., and Williams-Jacobse, J., Millpress, Rotterdam, 257-262, 2002.

Seiler, W., and Crutzen, P. J.: Estimates of gross and net fluxes of carbon between the biosphere and the atmosphere from biomass burning, Clim. Change, 2, 207-247, 1980.

Spahni, R., Wania, R., Neef, L., van Weele, M., Pison, I., Bousquet, P., Frankenberg, C., Foster, P. N., Joos, F., Prentice, I. C., and van Velthoven, P.: Constraining global methane emissions and uptake by ecosystems, Biogeosciences, 8, 1643-1665, doi:10.5194/bg-8-1643-2011, 2011.

Takeuchi, W. and Yasuoka, Y.: Spatio-temporal evaluation of a method to map paddy fields fraction coverage, J. Remote. Sens. Soc. Jpn, 26, 146-153, 2006.

Thonicke, K., Venevsky, S., Sitch, S., and Cramer, W.: The role of fire disturbance for global vegetation dynamics: coupling fire into a Dynamic Global Vegetation Model, Global Ecol. Biogeogr., 10, 661-677, 2001.

Tian, H., Xu, X., Liu, M., Ren, W., Zhang, C., Chen, G., and Lu, C.: Spatial and temporal patterns of $\mathrm{CH}_{4}$ and $\mathrm{N}_{2} \mathrm{O}$ fluxes in terrestrial ecosystems of North America during 1979-2008: application of a global biogeochemistry model, Biogeosciences, 7, 2673-2694, doi:10.5194/bg-7-2673-2010, 2010.

van der Werf, G. R., Randerson, J. T., Giglio, L., Collatz, G. J., Mu, M., Kasibhatla, P. S., Morton, D. C., DeFries, R. S., Jin, Y., and van Leeuwen, T. T.: Global fire emissions and the contribution of deforestation, savanna, forest, agricultural, and peat fires (19972009), Atmos. Chem. Phys., 10, 11707-11735, doi:10.5194/acp10-11707-2010, 2010.

Walter, B. P. and Heimann, M.: A process-based, climate-sensitive model to derive methane emissions from natural wetlands: Application to five wetlands sites, sensitivity to model parameters, and climate, Global Biogeochem. Cy., 14, 745-765, 2000.

Wang, J. S., Logan, J. A., McElroy, M. B., Duncan, B. N., Megretskaia, I. A., and Yantosca, R. M.: A 3-D model analysis of the slowdown and interannual variability in the methane growth rate from 1988 to 1997, Global Biogeochem. Cy., 18, GB3011, doi:10.1029/2003GB002180, 2004.

Wania, R., Ross, I., and Prentice, I. C.: Implementation and evaluation of a new methane model within a dynamic global vegetation model: LPJ-WHyMe v1.3.1, Geosci. Model Dev., 3, 565-584, doi:10.5194/gmd-3-565-2010, 2010.

Wuebbles, D. J. and Hayhoe, K.: Atmospheric methane and global change, Earth Sci. Rev., 57, 177-210, 2002.

Yan, X., Akiyama, H., Yagi, K., and Akimoto, A.: Global estimations of the inventory and mitigation potential of methane emissions from rice cultivation conducted using the 2006 Intergovernmental Panel on Climate Change Guidelines, Global Biogeochem. Cy., 23, GB2002, doi:10.1029/2008GB003299, 2009. 
Yoshida, Y., Ota, Y., Eguchi, N., Kikuchi, N., Nobuta, K., Tran, H., Morino, I., and Yokota, T.: Retrieval algorithm for $\mathrm{CO}_{2}$ and $\mathrm{CH}_{4}$ column abundances from short-wavelength infrared spectral observations by the Greenhouse gases observing satellite, Atmos. Meas. Tech., 4, 717-734, doi:10.5194/amt-4-717-2011, 2011.

Zhang, Y., Li, C., Trettin, C. C., Li, H., and Sun, G.: An integrated model of soil, hydrology, and vegetation for carbon dynamics in wetland ecosystems, Global Biogeochem. Cy., 16, 1061, doi:10.1029/2001GB001838, 2002.
Zhuang, Q., Melillo, J. M., Kicklighter, D. W., Prinn, R. G., McGuire, A. D., Steudler, P. A., Felzer, B. S., and Hu, S.: Methane fluxes between terrestrial ecosystems and atmosphere at northern high latitudes during the past century: A retrospective analysis with a process-based biogeochemistry model, Global Biogeochem. Cy., 18, GB3010, doi:10.1029/2004GB002239, 2004. 